\title{
Penggunaan Bahan Ajar Outdoor Learning untuk Meningkatkan Kemampuan Pemecahan Masalah Matematis
}

\author{
Wanti Asmara ${ }^{1}$, Saleh Haji², Hanifah ${ }^{3}$ \\ ${ }^{123}$ Pascasarjana Pendidikan Matematika, Universitas Bengkulu, Indonesia \\ 1wanti.asmara@ymail.com, ${ }^{2}$ salehhaji@unib.ac.id, ${ }^{3}$ hanifah21@gmail.com
}

\section{INFO ARTIKEL}

\section{Riwayat Artikel:}

Diterima: 22-09-2018

Disetujui: 25-10-2018

\section{Kata Kunci:}

Outdoor Learning,

Pemecahan Masalah,

Matematis

\begin{abstract}
ABSTRAK
Abstrak: Tujuan penelitian ini adalah untuk mengetahui peningkatan kemampuan pemecahan masalah matematis siswa yang diajar menggunakan bahan ajar Outdoor Learning. Bahan ajar tersebut terdiri dari buku ajar dan LKPD. Jenis penelitian ini adalah quasi eksperiment (eksperimen semu) dengan populasi penelitian yaitu siswa kelas VII SMP Negeri 19 Kota Bengkulu. Hasil penelitian ini menyimpulkan bahwa penggunaan bahan ajar outdoor learning dapat meningkatkan kemampuan pemecahan masalah matematis siswa, dengan nilai $\mathrm{n}$-Gain 0,50 (sedang).
\end{abstract}

\begin{abstract}
The purpose of this study was to determine the improvement of students' mathematical problem solving abilities taught using Outdoor Learning teaching materials. The teaching materials consist of textbooks and LKPD. This type of research is quasi experiment (quasi-experimental) with the research population, namely grade VII students of Bengkulu City 19 Middle School. The results of this study conclude that the use of outdoor learning teaching materials can improve students' mathematical problem solving abilities, with a $n$-Gain value of 0.50 (moderate).
\end{abstract}

\section{A. LATAR BELAKANG}

Salah satu isu strategis yang harus dihadapi bangsa Indonesia sekarang ini adalah Masyarakat Ekonomi Asean (MEA). Stakeholder Indonesia tentu harus mengikuti standar internasional supaya dapat tetap survive di era global ini. Demikian halnya dunia pendidikan, termasuk pendidikan matematika. Pemerintah Indonesia telah melakukan berbagai upaya untuk memajukan pendidikan matematika di Indonesia. Perubahan tersebut dapat dilihat dengan adanya kebijakan pada setiap periode perubahan muatan kurikulum dan mereformasi tujuan pendidikan Indonesia, sebagai salah satu contoh, yaitu kurikulum 2013 yang merupakan produk dalam upaya pemerintah memperbaiki kualitas pendidikan Indonesia. Berdasarkan laporan terbaru dari evaluasi PISA 2012, kecakapan siswa Indonesia umur 15 tahun yang rata-rata berada di Sekolah Menengah pada bidang matematika masih berada pada posisi dua terbawah dan cendrung berada pada sepuluh terbawah pada periode-periode yang telah lalu (PISA 2009; PISA 2013).

Bahan ajar merupakan salah satu perangkat pembelajaran yang wajib dimiliki disetiap proses pembelajaran. Bahan ajar dapat berupa Rencana Pelaksanaan Pembelajaran (RPP), Lembar Kerja
Peserta Didik (LKPD), dan Buku Ajar. Sebagaimana yang dikatakan oleh Lestari (2013) bahan ajar adalah seperangkat sarana atau alat pembelajaran yang berisikan materi pembelajaran, metode, batasan-batasan, dan cara mengevaluasi yang didesain secara sistematis dan menarik dalam rangka mencapai tujuan yang diharapkan, yaitu mencapai kompetensi atau sub kompetensi dengan segala kompleksitasnya.

Sebagaimana yang kita ketahui bahwasanya pembelajaran di Sekolah baik itu tingkat dasar, menengah, maupun tingkat atas masih saja dilakukan secara biasa, yakni mendengarkan penjelasan dari guru kemudian dilanjutkan dengan mengerjakan latihan, juga dari segi perangkat pembelajaran, seperti bahan ajar yang digunakan di Sekolah. Bahan ajar merupakan komponen penting dalam pembelajaran, sebagaimana yang dikatakan oleh Walid dan Hidayah (2017) bahan ajar memiliki pengaruh dan peran sangat tinggi dalam proses pembelajaran. Hal ini disebabkan adanya hubungan guru, sumber belajar dan sisiwa. Salah satu cara untuk memperbaiki hasil pembelajaran matematika adalah dengan menggunakan bahan ajar yang sesuai dengan pembelajaran berikut lingkungan belajarnya termasuk sarana dan prasarana yang memadai 
agar pembelajaran lebih bermakna. Bahan ajar yang disampaikan seorang guru hendaknya mengacu kepada tujuan yang telah digariskan dalam kurikulum. Oleh karena itu, guru mempunyai keleluasaan untuk mengembangkan bahan ajar yang akan disampaikan sejauh tidak menyimpang dari tujuan.

Dalam pelaksanaan yang seharusnya guru merupakan fasilitator dalam pembelajaran, bagaimana peserta didik sebagai subjek belajar melakukan aktivitas untuk meningkatkan pengetahuannya. Guru seharusnya memfokuskan pengajaran pada pengembangan kecerdasan, fisik, dan emosi peserta didik, tanpa mengabaikan pembentukan karakter. Untuk itu diperlukan suatu pemilihan model pembelajaran yang sesuai yang dapat mencapai tujuan dari suatu pembelajaran yang ingin dicapai.

Pendidikan bukan hanya bagaimana cara untuk memperoleh pengetahuan, tetapi juga merupakan suatu upaya untuk meningkatkan pemahaman, sikap, dan ketrampilan serta perkembangan diri anak. Kemampuan atau kompetensi ini diharapkan dapat dicapai melalui berbagai proses pembelajaran di sekolah. Salah satu proses pembelajaran yang digunakan untuk mencapai kompetensi diatas adalah melalui pembelajaran diluar kelas (outdoor). Menurut Harte (2013) yang mengemukakan bahwa pembelajaran di luar ruangan merupakan salah satu cara untuk melibatkan anak kecil, karena banyak manfaatnya bagi anak, termasuk membantu anak menjadi lebih terhubung dengan situasi diluar rumah dan belajar mengenal objek luar. Pembelajaran melalui pengalaman langsung di luar kelas mempermudah siswa mempelajari materi. Pengalaman langsung di luar kelas juga dapat memperkuat penguasaan konsep yang diterima siswa dalam kelas. Menurut Broda (2011) yang menyebutkan "after an indoor presentation about geometricshapes, a treck to the schoolyard to find the same shapes in nature can make an abstract concept much more concrete". Pembelajaran siswa di luar kelas dapat memperkuat pemahaman konsep materi.

Pemecahan masalah sebagai salah satu aspek kemampuan berpikir tingkat tinggi. Polya (2014) menyatakan bahwa pemecahan masalah merupakan suatu tingkat aktivitas intelektual yang sangat tinggi. Pemecahan masalah adalah suatu aktivitas intelektual untuk mencari penyelesaiaan masalah yang dihadapi dengan menggunakan bekal pengetahuan yang sudah dimiliki. Menurut Brunner dalam (Trianto. 2010), jika siswa berusaha sendiri untuk mencari pemecahan masalah serta pengetahuan yang menyertainya, menghasilkan pengetahuan yang menyertainya, maka akan menghasilkan pengetahuan yang benarbenar bermakna.

Jadi rumusan masalah dalam penelitian ini yaitu apakah penggunaan bahan ajar outdoor learning dapat meningkatkan kemampuan pemecahan masalah matematis siswa SMP Negeri 19 Kota Bengkulu.

\section{B. METODE PENELITIAN}

Jenis penelitian ini adalah quasi eksperiment (eksperimen semu) dengan populasi penelitian yaitu siswa kelas VII SMP Negeri 19 Kota Bengkulu.

\section{HASIL DAN PEMBAHASAN}

Sebelum melakukan proses pembelajaran dengan menggunakan bahan ajar outdoor learning, diberikan pre-test dengan tujuan untuk mengetahui tingkat awal kemampuan pemecahan masalah peserta didik serta kesiapan peserta didik terhadap materi yang akan diajarkan. Bentuk tes yang diberikan berupa soal-soal uraian yang sesuai dengan indikator-indikator kemampuan pemecahan Masalah. Berdasarkan pre-test yang diberikan menunjukkan bahwa kemampuan awal kemampuan pemecahan masalah peserta didik Kelas Eksperimen masih tergolong rendah. Hal ini dapat diketahui dari hasil penskoran pre-test yang telah dilakukan dimana untuk kemampuan pemecahan masalah peserta didik rata-rata skor 9,48 atau dengan nilai rata-rata 32,7 dari skor total maksimum 29. Rendahnya skor peserta didik ini disebabkan oleh berbagai penyebab, diantaranya ada beberapa peserta didik yang langsung menjawab soal tanpa menganalisis masalah, ada peserta didik yang tidak membuat perencanaan jawaban ataupun kesimpulan jawaban, bahkan ada peserta didik yang tidak serius menjawab tes kemampuan tersebut.

Setelah pemberian pre-test barulah dilakukan perlakuan, yaitu dengan menerapkan pembelajaran luar kelas (outdoor learning). Proses pembelajaran yang dilakukan selama penelitian telah mengikuti semua sintaks outdoor learning, sehingga diharapkan dapat mengoptimalkan kemampuan pemecahan masalah peserta didik. Setelah dilakukan pembelajaran tersebut, maka diberikan postes pada akhir pertemuan. Berdasarkan postes yang diberikan menunjukkan bahwa kemampuan pemecahan masalah peserta 
didik Kelas Eksperimen tergolong pada kategori tinggi. Hal ini dapat dilihat dari hasil penskoran post-test yang telah dilakukan dan didapat ratarata skor 17,9 atau dengan nilai 61,7 dari skor total maksimum 29.

Pada penskoran N-Gain antara pretes dan postes kemampuan pemecahan masalah peserta didik rata-rata skor $\mathrm{N}$-gain 0,50 dengan kriteria $\mathrm{N}$ gain berkategori sedang. Dari skor peningkatan skor postes dan pretes serta dari skor N-gain maka pembelajaran dengan outdoor learning dapat meningkatkan kemampuan pemecahan masalah dan kemampuan berpikir kreatif peserta didik.

Secara ringkas data hasil pretest dan posttest kemampuan pemecahan masalah peserta didik kelas eksperimen dan kelas kontrol disajikan dalam Tabel 1.

TABEL 1

DATA PRETEST DAN POSTEST KEMAMPUAN PEMECAHAN MASALAH PESERTA DIDIK KELAS EKSPERIMEN DAN KELAS KONTROL

\begin{tabular}{|c|c|c|c|c|}
\hline \multirow[b]{2}{*}{ Keterangan } & \multicolumn{2}{|c|}{ Kelas Eksperimen } & \multicolumn{2}{|c|}{ Kelas Kontrol } \\
\hline & $\begin{array}{c}\text { Skor } \\
\text { Pretest }\end{array}$ & $\begin{array}{c}\text { Skor } \\
\text { Postest }\end{array}$ & $\begin{array}{c}\text { Skor } \\
\text { Pretest }\end{array}$ & $\begin{array}{c}\text { Skor } \\
\text { Postest }\end{array}$ \\
\hline Rata-Rata $(\bar{X})$ & 32.58 & 61.71 & 27.10 & 50.23 \\
\hline Varian $\left(S^{2}\right)$ & 218.12 & 539.01 & 248.22 & 520.25 \\
\hline Simpangan Baku (S) & 14.77 & 23.22 & 15.76 & 22.81 \\
\hline Skor Minimal & 7 & 24 & 7 & 17 \\
\hline Skor Maksimal & 59 & 93 & 55 & 93 \\
\hline Rata-rata Skor N-Gain & \multicolumn{2}{|c|}{0.50} & \multicolumn{2}{|c|}{0.36} \\
\hline
\end{tabular}

Data tersebut, dapat dibuat dengan Gambar 1 berikut ini:

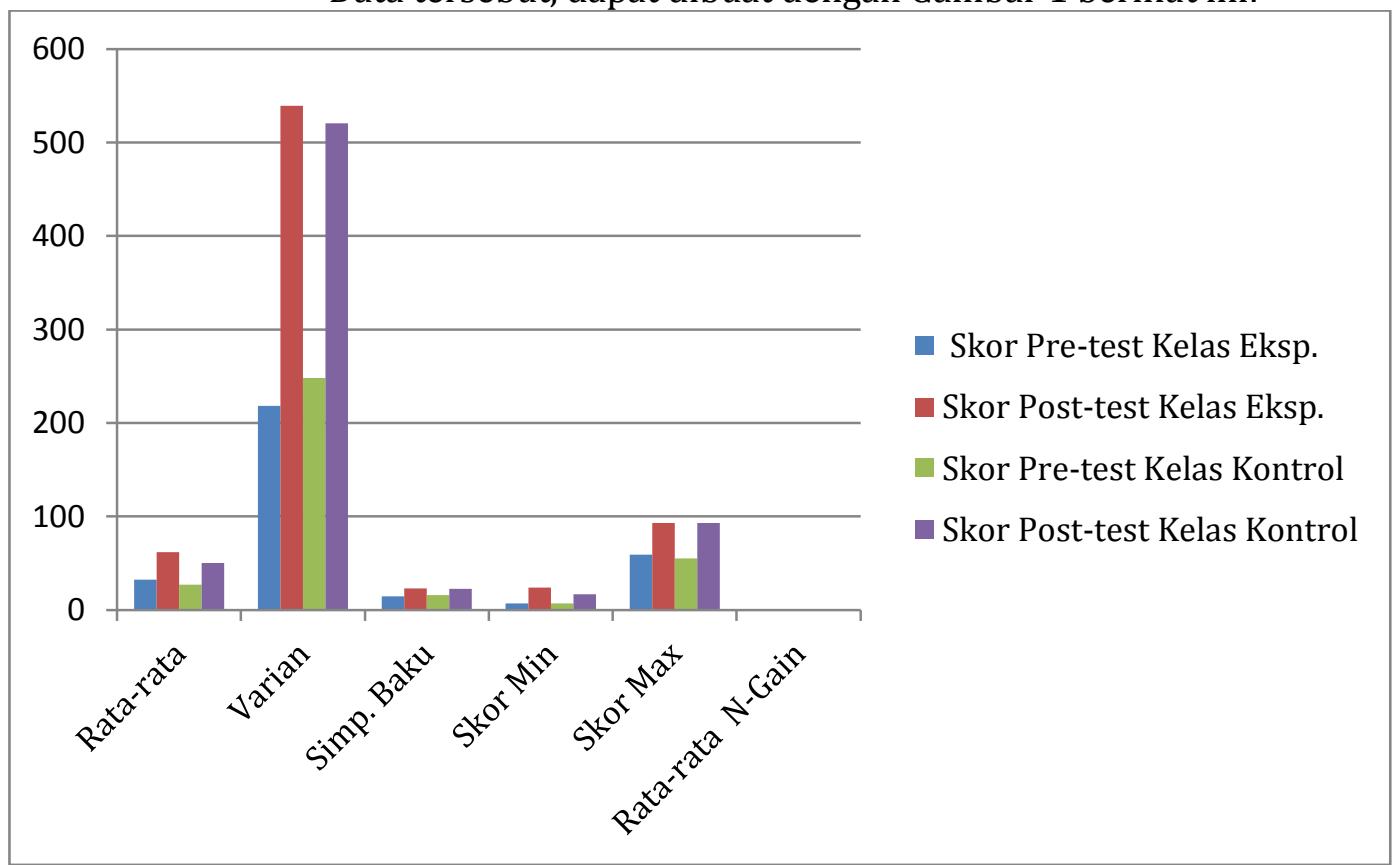

Gambar 1. Histogram Skor Kemampuan Pemecahan Masalah

Berdasarkan Tabel 1. diperoleh rata-rata skor pretes, rata-rata postes dan rata-rata skor n-Gain kemampuan pemecahan masalah peserta didik kelas eksperimen lebih tinggi dibandingkan kelas kontrol sehingga terdapat peningkatan nilai kemampuan pemecahan masalah lebih tinggi dari penigkatan kelas kontrol.

Berdasarkan hasil pretes, postes dan rata-rata Ngain kemampuan pemecahan masalah peserta didik baik kelas eksperimen maupun kelas kontrol menunjukkan bahwa rata-rata skor kemampuan pemecahan masalah peserta didik kelas eksperimen lebih tinggi dibandingkan kelas kontrol, serta terjadi peningkatan rata-rata skor dari sebelum perlakuan dengan sesudah perlakuan baik kelas eksperimen maupun kelas kontrol. Perhitungan data hasil pretest dan postest kemampuan pemecahan masalah peserta 
didik dilakukan secara manual dibantu dengan menggunakan program Microsoft Excel 2010.

Hal ini disebabkan oleh penggunaan bahan ajar outdoor learning yang membuat siswa menjadi lebih aktif dan kreatif karena langsung berhubungan dengan masalah yang ada di kehidupan (luar kelas).

\section{SIMPULAN DAN SARAN}

Berdasarkan penelian yang telah dilakukan dapat disimpulkan bahwa penggunaan bahan ajar matematika dalam pembelajaran luar kelas dapat meningkatkan kemampuan pemecahan masalah matematis dengan nilai peningkatan ( $\mathrm{N}$-gain) sebesar 0,50 (yang berarti meningkat). Hal ini dikarenakan siswa saat melakukan pembelajaran luar kelas, siswa berhubungan langsung dengan dunia nyata sebagai objek pembelajaran. Siswa juga menjadi lebih bersosialisasi dengan lingkungan, baik itu teman sekelas ataupun masyarakat yang berada disekitar objek belajar. Sehingga dapat disimpulkan dengan menggunakan bahan ajar matematika dalam pembelajaran luar kelas (outdoor learning) dapat meningkatkan kemampuan pemecahan masalah matematis siswa.

Bagi para peneliti yang ingin melakukan penelitian, bisa mengangkat judul artikel ini yakni penerapan bahan ajar outdoor learning, untuk meningkatkan kemampuan pemecahan masalah matematis siswa, baik itu penelitian pengembangan ataupun eksperimen.

\section{REFERENSI}

[1] Broda, H. W. (2011). Moving the classroom outdoors: Schoolyard-enhanced learning in action. Stenhouse Publishers.

[2] Harte, H. A. (2013). Universal design and outdoor learning. Dimensions of Early Childhood, 41(3), 18-22.

[3] Lestari, Ika. (2013). Pengembangan Bahan Ajar Berbasis Kompetensi: Sesuai dengan Kurikulum Tingkat Satuan Pendidikan. Padang: Akademia.

[4] Polya, G. (2014). How to solve it: A new aspect of mathematical method. Princeton university press.

[5] Organisation for Economic Co-operation and Development. (2010). PISA 2009 Results: What Students Know and Can Do-Student Performance in Reading, Mathematics, and Science (Volume I). Paris: OECD Publishing.

[6] Meyer, H. D., \& Benavot, A. (Eds.). (2013, May). PISA, power, and policy: The emergence of global educational governance. Symposium Books Ltd.

[7] Trianto. (2010). Mendesain Model Pembelajaran Inovatif-Progresif. Penata Media Group: Jakarta

[8] Walid, M., \& Hanifah, N. H. (2018). Pengembangan Buku Ajar Tematik Kelas Iv Berbasis Integrasi Islam Pada Subtema Pemanfaatan Energi Di Sekolah Dasar. JMIE Uournal of Madrasah Ibtidaiyah 